\title{
Ecological and Functional Evaluation of Species Candidate for Heavy Metals Phytoremediation in SIN Porto Torres (Sardinia, Italy)
}

\author{
Guarino $C^{*}$ and Sciarrillo $\mathbf{R}$ \\ Department of Science and Technology, University of Sannio, via Port'Arsa 11, 82100 Benevento, Italy
}

\begin{abstract}
The pollution of metals and metalloids in soils caused by industrial activities is a major issue and invests the whole planet earth. The area we investigated is present in the Petrochemical of Porto Torres (Sardinia-Italy), which has an extension of about 1100 ha, is located along the northwest coast of Sardinia, about $1.8 \mathrm{~km}$ west of the town and with a surface contamination (0-50 cm depth) from As, TI and V. The aim of this study is the investigation of spontaneous species present in the areas and the possibility to find some species among those useful to the phytoremediation. We also evaluate (mesocosm) some species that spontaneously live in the Porto Torres area but not on the area under consideration such as Dittrichia viscosa and Piptatherum miliaceum which, according to literature data, showed a good attitude towards phytoremediation. In conclusion, Dittrichia viscosa, Piptatherum miliaceum and Bromus madritensis are good candidates to build a phytoremediation design.
\end{abstract}

Keywords: Heavy metal; Dittrichia viscosa; Piptatherum miliaceum; Bromus madritensis

\section{Introduction}

The pollution of metals and metalloids in soils caused by industrial activities is a major issue and invests the whole planet earth [1-3]. Indeed, with the industrial crisis, many areas of industrial production have been closed and therefore the relevant areas have been abandoned to themselves. Only in Italy there are 39 Sites of National Interest (ISPRA Source: January 11, 2013) where it calls for a resolution for environmental rehabilitation.

There are areas with a high environmental risk where the diversity of the pollutant matrix must include specific studies and analyzes for risk control and elimination. The techniques used to eliminate these problems were mainly those to dig and dump, only afterwards it was possible to use in-situ chemical-physical techniques that, while some of the problems to be solved, caused several side effects such as destruction of particular Ecosystems [4,5]. An alternative to these recent years has been proposed (where stationary conditions allow) a technology that has as its main element the plant species and their interactions with mushrooms and bacteria, and thus a sustainable, gentle and reliable technology. Phyto-technologies in recent years have made giant steps and have clarified and discovered mechanisms for responding to abiotic stresses with particular regard to detoxification strategies from pollutant. In addition, natural capacity of the plants was demonstrated in relation to their fungus, mycorrhiza and bacteria dominated rhizosphere [6-8].

In relation to these premises, it is important to know the spontaneous vegetation that grows in the polluting places, since it is possible to get the first clues to approach the problem. In fact, these sites insist on selected natural vegetation in relation to the pollutants that we can define pseudo-metallophytes in accordance with the particular metabolic detoxification features they implement. These mechanisms are very important in heavily polluted sites. Moreover, these investigations allow sites where to apply phytoremediation not to cause further cenotic pollution by using exotic species and extracted from the environmental context. In fact, it is assumed that the vegetation present and well suited to the environmental conditions of the site, given the semiarid character of the Mediterranean basin and in particular on the site of Porto Marghera [9,10].

In general, according to our point of view, the methodological approach to the project of waste disposal must firstly include the use of species that already exist on the site subject to reclamation and which meet the requirements of wastewater as bioaccumulation and translocation factors. If these plant species do not meet the required requirements, it is possible to refer to plants which in the literature have shown the useful characteristics and possibly, in the first analysis, you have to choose Mediterranean species present in adjacent areas to the site subject of the intervention. These are useful parameters for a proper ecological approach and are determined for the success of reclamation $[1,11]$.

The area we investigated is present in the petrochemical of Porto Torres (Sardinia-Italy), which has an extension of about 1100 ha, is located along the northwest coast of Sardinia, about $1.8 \mathrm{~km}$ west of the town. In part, the industrial area is still active. The area we investigated is part of the D sector (about 400 ha) for an extension of about 70 hectares. It corresponds to a currently non-urbanized area used for pastoral activities in the past. The area is currently fenced. The environment in which the study area is located is characterized by a series of mediumheight hills, falsified walls and planks partially molded in limestone sediments. Overall, the area is embedded in an environment in which landscape forms come from the joint action of several factors (atmospheric events, river erosion, etc.), among which an important role is played by tectonics.

In this study we face surface contamination $(0-50 \mathrm{~cm}$ depth $)$ from As, $\mathrm{Tl}$ and $\mathrm{V}$ of the areas through the investigation of spontaneous species present in the areas and the possibility to find some species among those useful to the phytoremediation. We also evaluate (mesocosm) some species that spontaneously live in the Porto Torres area but not on the

*Corresponding author: Carmine Guarino, Department of Science and Technology, University of Sannio, via Port'Arsa 11, 82100 Benevento, Italy, Tel: +390824305142; E-mail: guarino@unisannio.it

Received June 15, 2017; Accepted June 20, 2017; Published June 26, 2017

Citation: Guarino C, Sciarrillo R (2017) Ecological and Functional Evaluation of Species Candidate for Heavy Metals Phytoremediation in SIN Porto Torres (Sardinia, Italy). J Environ Anal Toxicol 7: 484. doi: 10.4172/2161-0525.1000484

Copyright: @ 2017 Guarino C, et al. This is an open-access article distributed under the terms of the Creative Commons Attribution License, which permits unrestricted use, distribution, and reproduction in any medium, provided the original author and source are credited. 
Citation: Guarino C, Sciarrillo R (2017) Ecological and Functional Evaluation of Species Candidate for Heavy Metals Phytoremediation in SIN Porto Torres (Sardinia, Italy). J Environ Anal Toxicol 7: 484. doi: 10.4172/2161-0525.1000484

Page 2 of 10

area under consideration such as Dittrichia viscosa and Piptatherum miliaceum which, according to literature data, showed a good attitude towards phytoremediation [12-17].

\section{Materials and Methods}

\section{Framing of the survey site}

The petrochemical of Porto Torres (Figure 1), the total area equal to $1106 \mathrm{ha}$, is located on the northwest coast of Sardinia, about $1.8 \mathrm{~km}$ west of the town from which it takes its name and is defined:

- north from the structures and docks of the industrial port inserted in the Gulf of Asinara;

- east of the former Ferriere Sarde and Brick Torres;

- south by land owned by the Consortium for the Industrial Development Area (CASIS) which houses many disparate industries (building products, manufacturing and marketing of plastics, deposits of mineral oil and LPG, shipbuilding) some craft activities;

- west from third owned land.

The Sector "D", outside the fence of the plant, is about 376 has within this field is the study area "D2 Area" located between the border of the Syndial plant, the Flumen Santu (or Holy River) - watercourse flowing at about $600 \mathrm{~W}$ but, the sea - but at about $500 \mathrm{~N}$, and the upstream Elva about 500 but SW. Overall, the D2 area occupies an area of approximately 70 ha. It corresponds to a currently undeveloped area (Figure 1), in the past used for herding activities, where it is not reported the realization of structures or systems or other human activities. The D2 Area is located approximately $500 \mathrm{~m} \mathrm{~S}$ of the coast line, at an average altitude of $32 \mathrm{~m}$ s.l.m. The environment is characterized by a series of hills of medium height, modeled in part in calcareous sediments. Overall, the area D2 is inserted in an environment in which the shapes of the landscape arising from the joint action of several factors (atmospheric events, fluvial erosion, etc.) among which an important role is played by tectonics. Under the geomorphologic profile, this environment is characterized by very steep and hilly shapes that resemble, in some sections, the antiTuscan Apennine region. Such forms are essentially due to erosion of lithologies that constitute the substrate (predominantly dolomitic limestone, marl arenaceous, marly limestone). The main valleys axes are oriented in the direction N-S, NE-SW and NW-SE in close correlation with the direction of the main tectonic systems present in the area under consideration. The Web site corresponds to an essentially flat morphological high, weakly sloping towards NW, interrupted to E by an escarpment oriented N-S. The slope, which coincides with a fault system oriented in the same direction, D2 separates the area from a morphologically depressed area in which there are some standing water. The height difference between the Area D2 eastern border and the adjacent depressed area is about $15 \mathrm{~m}$. The Characterization Plan of the site in question has identified with regard to land are exceeded for arsenic in topsoil. The exceedances of arsenic are in the range 50-220 $\mathrm{mg} / \mathrm{kg}$.

\section{Analysis of the natural vegetation in site}

In the first analysis, it proceeded to evaluating the potential for phytoremediation of spontaneous species present in the site by assessing the spatial diffusion and the capacity to assimilate the contaminants present in the matrix. An analysis of the soil characterization data is obtained that the area suffers from a contamination by As, $\mathrm{Tl}$ and $\mathrm{V}$ clearly confined to the most superficial profile of the soil. From these considerations, it is assessed 4 sufficient to identify sampling areas of soil and vegetation. The four sampling areas correspond to a circumference of approximately $2.800 \mathrm{~m}^{2}$ having as its center the piezometers D1SP0031 (area 1) and D1SP0027 (area 2) and an equivalent area but projected from the perimeter towards the inside of the D2 site ANIC for piezometers D1SP0070 (area 3) and D1SP0041 (area 4). The 1-23-4 areas correspond to the Thiessen polygons with $\mathrm{Ci}>\mathrm{CSC}$ (Figure $1)$; therefore, all of the soil and vegetation samplings were performed in areas characterized by concentrations of As Tl and V> CSC. All sampling points were georeferenced (Table 1) and shown in the Figure 1. In the sampling areas indicated in Figure 1 were detected the most widespread plant species (Table 2 and Figure 2). Five individuals per species were collected, taking care to also extract the entire root system. In addition to the plant sample, in an amount of $0-2 \mathrm{~cm}$ rhizosphere soil it was taken sufficient to conduct the subsequent characterization and analysis of heavy metals.

Soil: Chemical analyses: Soil samples were analyzed in order to characterize their main physical and chemical properties; in particular, the following parameters were studied: humidity at $105^{\circ} \mathrm{C}, \mathrm{pH}, \mathrm{EC}$ at $25^{\circ} \mathrm{C}$, total carbonates, CEC, organic Carbon, total $\mathrm{N}, \mathrm{C} / \mathrm{N}$, and total content of $\mathrm{As}, \mathrm{Cd}, \mathrm{Cu}, \mathrm{Pb}, \mathrm{Tl}, \mathrm{V} \mathrm{Zn}$. Soil samples were ovendried at $105^{\circ} \mathrm{C}$ for 24 hand acid-digested in a microwave oven (CEM, MARSXpress) according to the USEPA method, (USEPA). After mineralization, soil extracts were filtered (0.45 mPTFE), diluted and analyzed. Total content of $\mathrm{As}, \mathrm{Cd}, \mathrm{Cu}, \mathrm{Pb}, \mathrm{Tl}, \mathrm{V}$ and $\mathrm{Zn}$ in soils extracts were determined by an ICP-OES (Varian Inc., VistaMPX). The accuracy of the analytical procedure adopted for ICP-OES analysis was checked by running standard solutions every 20 samples. Yttrium was used as the internal standard. A reagent blank and certified reference material (NIST SRM ${ }^{\circ} 2710$ a Montana soil and NIST SRM ${ }^{\circ} 1573$ tomato leaves, for soils and plants, respectively) were included for quality control of analysis.

The mean concentrations of heavy metals in soil were compared with values for residential soils (Table 1A of D.Lgs. 152/06). The bioavailable fraction of $\mathrm{Cd}, \mathrm{Cu}, \mathrm{Pb}$ e $\mathrm{Zn}$ in soil was determined following Lindsay and Norwell [18]. The method consisted of a sequential extraction with $\mathrm{H}_{2} \mathrm{O}, \mathrm{KNO}_{3} 1 \mathrm{M}$ and EDTA $2 \mathrm{mM}$; in order to promote the comparison with microcosm experiments, molarity of EDTA solution was modified from the original procedure $[19,20]$. The bioavailable fraction of As, $\mathrm{Tl}$ and $\mathrm{V}$ was determined by extraction in ammonium acetate $[21,22]$.

Plant: Chemical analyses: Plants samples were divided into roots and shoots, washed gently with deionized distilled water for approximately $3 \mathrm{~min}$ to remove soil particles adhered to the plants. After washing, plant samples were air dried at room temperature for two weeks and then ground to powders using a Wiley Mill.

\section{Experimentation in microcosm (columns)}

Microcosm experimentation has been set up to verify the adequacy of phosphate based mineral fertilization of site in order to increase the performance of the plants to be used for phytoremediation. Six microcosms of PVC were made. The soil used in micro- and mesocosms was taken in July 2012 at Areas 1,2,3 and 4 in the D2 sector. With the homogenized soil of the 4 areas the microcosms were filled and then left to balance for 10 days. The total volume of the cylinder is about 9.7 L. It has 4 holes arranged orthogonally between them at 10-20-30-40 $\mathrm{cm}$ in order to be able to have porous cups to extract interstitial water samples at different heights. It is also possible to recover the leachate of the column by means of a tap located at the base of the column.

The instrument used to capture the interstitial water of the columns 
Citation: Guarino C, Sciarrillo R (2017) Ecological and Functional Evaluation of Species Candidate for Heavy Metals Phytoremediation in SIN Porto Torres (Sardinia, Italy). J Environ Anal Toxicol 7: 484. doi: 10.4172/2161-0525.1000484
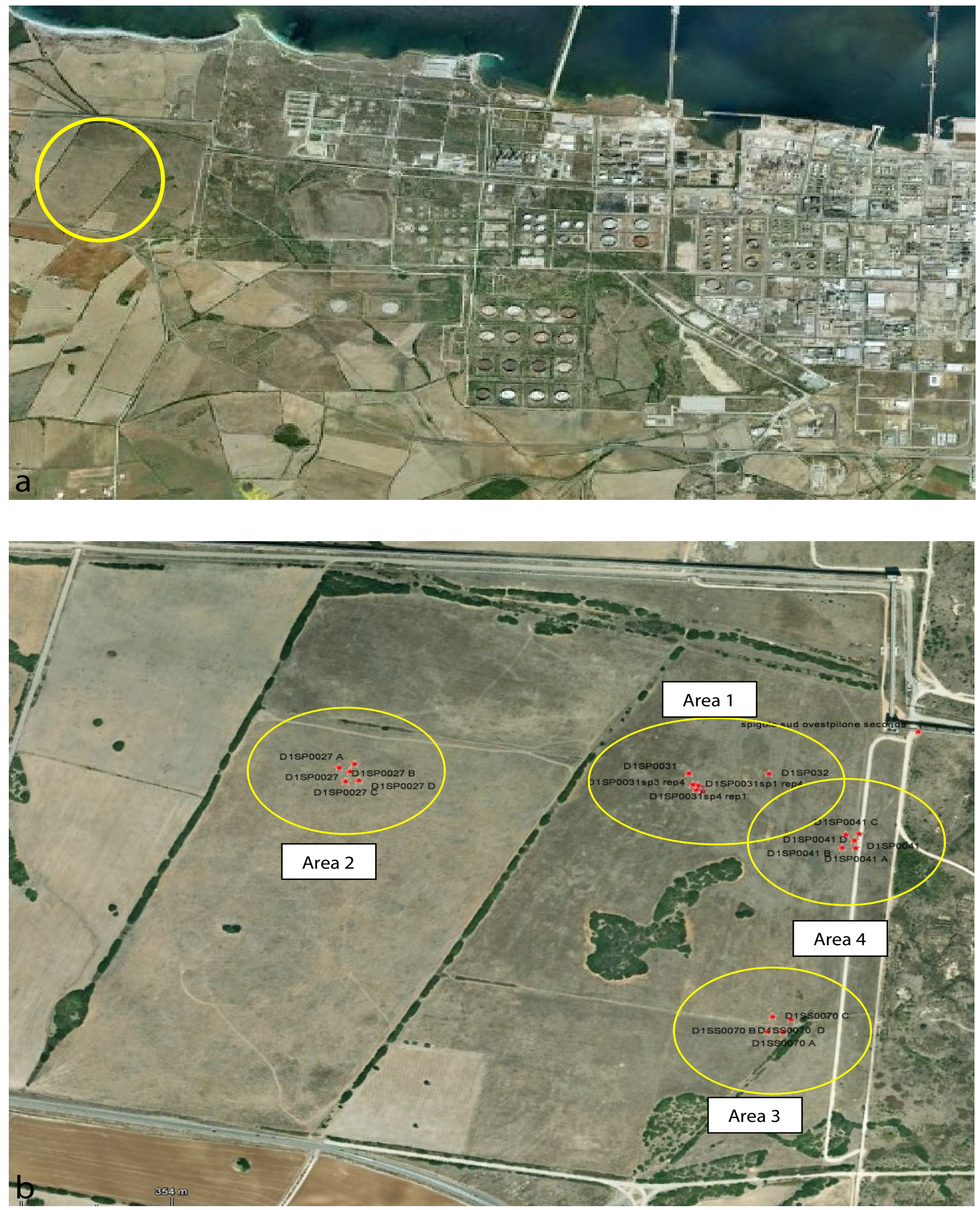

Figure 1: a) Satellite image of the plant with evidence (in yellow) D2 sector. b) Sampling areas and georeferenced points. 
Citation: Guarino C, Sciarrillo R (2017) Ecological and Functional Evaluation of Species Candidate for Heavy Metals Phytoremediation in SIN Porto Torres (Sardinia, Italy). J Environ Anal Toxicol 7: 484. doi: 10.4172/2161-0525.1000484

Page 4 of 10

\begin{tabular}{|c|c|c|}
\hline \multirow{2}{*}{ Sampling Point } & \multicolumn{2}{|c|}{ Geographic Coordinates (WGS 84) } \\
\cline { 2 - 3 } & X & Y \\
\hline D1SP0031_A & 8,32327 & 40,83473 \\
\hline D1SP0031_B & 8,32331 & 40,83466 \\
\hline D1SP0031_C & 8,32331 & 40,83466 \\
\hline D1SP0031_D & 8,32334 & 40,83472 \\
\hline D1SP0027_A & 8,31851 & 40,83501 \\
\hline D1SP0027_B & 8,31829 & 40,83497 \\
\hline D1SP0027_C & 8,31838 & 40,83487 \\
\hline D1SP0027_D & 8,31857 & 40,83479 \\
\hline D1SS0070_A & 8,32453 & 40,83134 \\
\hline D1SS0070_B & 8,32431 & 40,83135 \\
\hline D1SS0070_C & 8,32438 & 40,83155 \\
\hline D1SS0070_D & 8,32464 & 40,83151 \\
\hline D1SP0041_A & 8,32557 & 40,83386 \\
\hline D1SP0041_B & 8,32538 & 40,83387 \\
\hline D1SP0041_C & 8,32543 & 40,83405 \\
\hline D1SP0041_D & 8,32562 & 40,83406 \\
\hline
\end{tabular}

Table 1: Geographic coordinates of the sampling points of the extracted species.

\begin{tabular}{|c|c|c|c|}
\hline Areas & $\begin{array}{c}\text { No. } \\
\text { individuals }\end{array}$ & Specie & Family \\
\hline \multirow{5}{*}{1} & 5 & Scolymushi spanicus & Asteraceae \\
\hline & 5 & Bromus madritensis & Poaceae \\
\hline & 5 & Dasypyrum villosum & Poaceae \\
\hline & 5 & Bromus hordeaceus & Poaceae \\
\hline & 5 & Hirschfeldia incana & Brassicaceae \\
\hline \multirow{5}{*}{2} & 5 & Bromus madritensis & Poaceae \\
\hline & 5 & Cardus pycnocephalus & Asteraceae \\
\hline & 5 & Hordeum murinum & Poaceae \\
\hline & 5 & Hirshfeldia incana & Brassicaceae \\
\hline & 5 & Bromus madritensis & Poaceae \\
\hline \multirow{6}{*}{3} & 5 & Bromus hordeaceus & Poaceae \\
\hline & 5 & Hordeum murinum & Poaceae \\
\hline & 5 & Hirshfeldia incana & Brassicaceae \\
\hline & 5 & Bromus hordeaceus & Poaceae \\
\hline & 5 & Anacyclus tomentosus & Asteraceae \\
\hline & 5 & Echium plantagineum & Boraginaceae \\
\hline
\end{tabular}

Table 2: Plant species sampled in the four areas.

during the percolation test is the Rhizon ${ }^{\circledR}$ (Eijkelkamp, NL). Mineral fertilization was administered twice a week in liquid form in the form of NP (17,5-44) of which urea nitrogen $\left(\mathrm{N}^{-\mathrm{NH}_{2}}\right)$ and phosphoric anhydride $\left(\mathrm{P}_{2} \mathrm{O}_{5}\right)$ soluble in water. The microcosms were filled by providing 3 replicas for each treatment including the control thesis (socalled soil) according to the following scheme:

- No. 3 microcosms with no fertilization (control thesis);

- No. 3 Microcosms with NP fertilization (Thesis P).

A 6-step admixture has been started every 72 hours. Prior to the next harvest, samples of percolation water from the bottom of microcosms and interstitial water samples (free of gravitational water) were collected at different heights of the column using the Rhizon ${ }^{\circ}$. The water samples were acidified and stored for subsequent elemental analyzes (As, $\mathrm{Tl}$ and $\mathrm{V}$ ); moreover, the volumes were recorded and the $\mathrm{pH}$ and conductivity values (EC) were determined.

\section{Experimentation in mesocosm (pot)}

Based on the data from the screening of the species found on the site (Supplementary Tables 1 and 2) it was decided to use only one of the species, Bromus madritensis (Poaceae). Therefore, two other species such as Dittrichia viscosa (Asteracea) and Piptatherum miliaceum (Poaceae) were used for experimentation in mesocosm on the basis of three different criteria. The first one necessarily refers to literature data showing a certain level of metal tolerance for the species considered. The second criterion is phytosociological since it is a species naturally present in the Porto Torres area. The third criterion is related to possible energy valorization or products derived from biomass produced.

Various species of Poaceae including Bromus madritensis and Piptatherum miliaceum are well known in the literature for the heavy metals and metalloids [23,24]. Dittrichia viscosa shows a strong tendency to bioaccumulation mainly in the roots of particular metals including $\mathrm{Tl}, \mathrm{V}$ and As [1,2]. Moreover, all these species considered have a potential for the exploitation of biomasses, particularly Dittrichia viscosa and Piptatherum miliaceum [25].

The experimentation in mesocosm was set up in the "Fitorimedio" greenhouse of the experimental farm of the Sannio University, using sowing seeds of $1.5 \mathrm{~kg}$ homogenized soil of the 4 areas in 4 replicas. The growing conditions of the greenhouse were $14 \mathrm{~h} 22^{\circ} \mathrm{C} / 10 \mathrm{~h} 18^{\circ} \mathrm{C}$ day / night regime and $65 \% \mathrm{RH}$. The growth period was 60 days. The plants were directly seeded in pots using 4 seeds pot $^{-1}$ for Dittrichia viscosa, 5 seed pot $^{-1}$ for Piptatherum miliaceum and 7 seeds pot $^{-1}$ for Bromus madritensis. Phospho-nitrogen fertilization was carried out on the $20^{\text {th }}$ and $40^{\text {th }}$ day from sowing in quantities of $40 \mathrm{~g}$ per pots. At the end of the $60^{\text {th }}$ day the plants were divided in aerial part and roots and analyzed for the dry substance and the absorption of As, $\mathrm{Tl}$ and $\mathrm{V}$ as described above.

\section{Ecophysiology plants}

Stress marker in plant ecophysiology were investigated in leaves of Dittrichia viscosa, Piptatherum miliaceaum and Bromus madritensis. In particular, Glutathione S-Transferase (GST) and Phenylalanine Ammonia Lyase (PAL) were evaluated in thirty samples as follows. 250 $\mathrm{mg}$ of leaves were homogenized under liquid nitrogen with mortar and pestle to a fine powder. The pigments were extracted in the dark in cold acetone $80 \%(\mathrm{v} / \mathrm{v})$, centrifuged $10 \mathrm{~min}$ at $19000 \mathrm{~g}$. The supernatant was analyzed spectrophotometrically by SmartSpec Plus (BIO-RAD) at the absorbance of $663.2,646.8,470 \mathrm{~nm}$. The dust was resuspended in 1.5 $\mathrm{ml}$ cold potassium phosphate buffer $(0.1 \mathrm{M} \mathrm{pH} 6.5$, EDTA $1 \mathrm{mM})$ at $4^{\circ} \mathrm{C}$. The homogenate was centrifuged at $4^{\circ} \mathrm{C}$ at $7000 \mathrm{~g}$ for $30 \mathrm{~min}$. The supernatant was used as the enzyme extract and carried out at $4^{\circ} \mathrm{C}$. The activity was evaluated spectrophotometrically by following the increase of the absorbance $(340 \mathrm{~nm})$ for $5 \mathrm{~min}$ at $25^{\circ} \mathrm{C}$ due to the conjugation of GSH to 1-chloro-2,4-dinitrobenzene (CDNB) catalyzed by GST. The reaction mixture contained potassium phosphate buffer $(0.1 \mathrm{mM}, \mathrm{pH}$ 6.5; $900 \mu \mathrm{l}), \mathrm{CDNB}(40 \mathrm{mM}, 25 \mu \mathrm{l})$, GSH ( $100 \mathrm{mM}, 50 \mu \mathrm{l})$, and enzyme extract $(25 \mu \mathrm{l}$ in a final volume of $1 \mathrm{ml}$ of the mixture). The activity was expressed as $\mu \mathrm{M} / \mathrm{min} / \mu \mathrm{g}$ protein. PAL activity was performed according to Forni et al. [26] method. The activity was expressed as $\mu \mathrm{g}$ $\mathrm{t}$-cinnamic acid/h/ $\mu \mathrm{g}$ protein.

\section{Statistical analysis}

All experiments were performed in triplicate. The Dixon's test was used to test the presence of outliers in the dataset. A test of normal distribution and homogeneity of variance was performed in order to choose the proper statistical tools. The assumption of normality 
Citation: Guarino C, Sciarrillo R (2017) Ecological and Functional Evaluation of Species Candidate for Heavy Metals Phytoremediation in SIN Porto Torres (Sardinia, Italy). J Environ Anal Toxicol 7: 484. doi: 10.4172/2161-0525.1000484
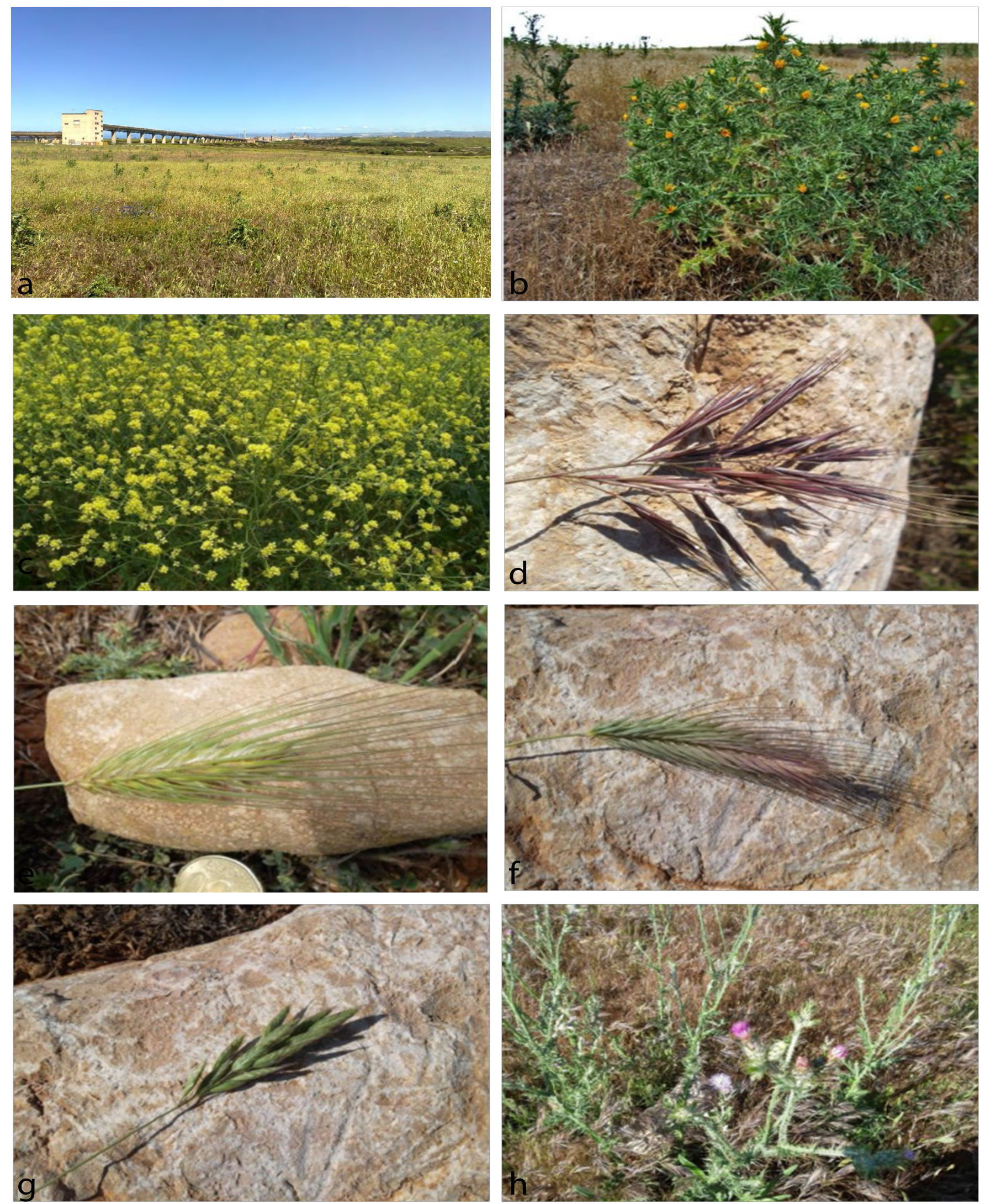

Figure 2: Photographic exhibition of sampled plants. a. Site; b. Scolymus hispanicus; c. Hirschfeldia incana; d. Bro-mus madritensis; e. Dasypyrum villosum; f. Hordeum murinum; g. Bromus hordaceum; h. Cardus pycnocephalus. 
Citation: Guarino C, Sciarrillo R (2017) Ecological and Functional Evaluation of Species Candidate for Heavy Metals Phytoremediation in SIN Porto Torres (Sardinia, Italy). J Environ Anal Toxicol 7: 484. doi: 10.4172/2161-0525.1000484

Page 6 of 10

underlying ANOVA was violated by several variables so non-parametric tests were used. Differences between groups were first tested using Tukey' tests.

\section{Results and Discussion}

\section{Soil characterization}

On soil samples we were determined the following parameters: $\mathrm{pH}$, electrical conductivity (EC $\left.\mathrm{mS} \mathrm{cm}^{-1}\right)$, cation exchange capacity (CEC meq/100 g), organic carbon (C org\% w/w), total nitrogen (Total $\mathrm{N} \mathrm{mg} / \mathrm{kg})$, assimilable phosphorus $\left(\mathrm{P}_{2} \mathrm{O}_{5} \mathrm{mg} / \mathrm{kg}\right)$ and exchangeable potassium $\left(\mathrm{K}_{2} \mathrm{O} \mathrm{mg} / \mathrm{kg}\right)$. From the analytical results reveal no anomaly in the soil of the investigated areas (Table 2). All samples showed an alkaline $\mathrm{pH}$ ranging between 7.15 and 8.21 with average EC and CEC values of $129 \mu \mathrm{Scm}^{-1}$ and $15 \mathrm{meq} / 100 \mathrm{~g}$, respectively in the four areas. The organic matter (OM) content (\%) was ranged from 1.44 to $2.39 \%$. with an average of $1.97 \%$. The efficiency of soil OM transformation processes was assessed through the $\mathrm{C} / \mathrm{N}$ ratio which showed an average value of 10.8 in all areas highlighting a balance between organic matter humidified and mineralized (Table 3).

\section{Determination of total content and bioavailability of metal in soil}

On aliquots of the same samples we were conducted the analysis for the determination of the total concentration of the metals and metalloids present. In order to be able to analyze in more depth the soil / plant relationships with particular reference to assimilation of heavy metals present in the contaminated substrate, it was determined by the bioavailable fraction of the elements. According to surveys conducted previously in the Area D2, emerges in critical concentrations of As, Tl and V according to the Legislative Decree 152/06. For other concentrations of the data elements are in the norm (Legislative Decree 152/06)(data not shown). In fact, in the soil it analyzed the average levels of concentration values of total As results are slightly higher than the threshold Legislative Decree 152/06 in 4 stations (average: $46.3 \pm$ $7.25 \mathrm{mg} / \mathrm{kg}$ ) (Table 4). The mean concentrations of Tl (1.65 $\pm 9.75 \mathrm{mg} /$ $\mathrm{kg})$ and $\mathrm{V}(1.65 \pm 0.03 \mathrm{mg} / \mathrm{kg})$ in soil were higher than the permissible threshold values for residential soils (D Lgs 152/06) by recovery rate of 1 and $90 \mathrm{mg} / \mathrm{kg}$ respectively (Table 4 ).

The concentration values of the bioavailable fraction are very low and this is particularly comforting for those elements for which have been demonstrated deviations from the thresholds established by Legislative Decree 152/06 (Table 5). The bioavailable fraction of As in the four areas is on average $5.22 \pm 0.01 \mathrm{mg} / \mathrm{kg}$; while of $\mathrm{Tl}$ and $\mathrm{V}$ are $0.24 \pm 0.02 \mathrm{mg} / \mathrm{kg}$ and $7.09 \pm 0.04 \mathrm{mg} / \mathrm{kg}$ (Table 5).

\section{Microcosm experiment (columns): Evaluation of effects of phosphatic fertilization}

The aim of the experiment in columns is to check the amount of leaching of the pollutant following phosphate fertilization in the absence of plants. At the basis of this experimental choice is the fact that the chemical behavior of the arsenic ion (AsV) is very similar to that of phosphate, in fact both anions are adsorbed in a specific way by the soil constituents forming on the surfaces of the charged minerals. The mobility of the lithium-ion generator (eg, aluminum oxide, iron, manganese, allophane, imogolite) Arsenic in the soil in the presence of phosphate ions is influenced by numerous factors such as $\mathrm{pH}$, molar ratio arsenate / phosphate, nature and properties of adsorbents and contact time between anions and adsorbent surfaces. The application of phosphate fertilizers can play an important role in releasing arsenic and arsenic ions in the circulating solution, thus also affecting the bioavailability of this element for plants. It has been observed that phosphate desorbs arsenic adsorbed by soil constituents. Addition of phosphate to polluted soils also results in a high displacement of the present arsenic, and the released arsenic fraction is partially readsorbed, partially absorbed by the plants and partially leached along the soil profile.

The concentration of As found in the percolates obtained from the microcosm test has two diverging trends for the two treatments to which the soil of Porto Torres has been subjected (Figure 3a). As can be seen, from the fourth sampling, the concentration of the control thesis, which has undergone irrigation with only demineralized water, exhibits a concentration far above that found for thesis $\mathrm{P}$, which has received phosphate fertilization. From these results, $\mathrm{P}$ results in even reducing the metalloid leaching.

Below are the data obtained from experimentation related to EC and $\mathrm{pH}$ in percolation water (Figure $3 \mathrm{~b}$ and $3 \mathrm{c}$ ). EC is a parameter that refers to the concentration of salts dissolved in percolation water. Administration of $\mathrm{P}$ with irrigation water (at the concentrations employed that correspond to those used in the experiment of mesocosm) did not cause significant variations in the percolating EC for almost the entire duration of the experiment (Figure 3b).

Figure $3 \mathrm{c}$ shows the average $\mathrm{pH}$ values. For this parameter it is not possible to identify an evolutionary trend outlined and distinguishable between the two treatments (CTRL and P). In the statistical analysis, the differences between the mean values were not significant for $\mathrm{pH}$ as for $\mathrm{CE}\left(\mathrm{pH} \mathrm{P}=8.09\right.$ and $\mathrm{pH} \mathrm{CTRL}=7.98, \mathrm{CE} \mathrm{P}=1.190 \mu \mathrm{cm}^{-1}$ and $\mathrm{CE}$ $\left.\mathrm{CTRL}=1.181 \mu \mathrm{S} \mathrm{cm}^{-1}\right)$.

It can be concluded that P-based mineral fertilization, at concentrations considered for plants, does not cause significant variations in percolation for the two parameters.

\section{Mesocosm experiment (pots)}

The objective of experimentation in mesocosm (pots) is to verify:

(A) the growth and development of plants in the presence of contamination by $\mathrm{As}, \mathrm{Tl}$ and $\mathrm{V}$;

(B) the extent of absorption and translocation of metals and metalloids in epigeal and hypogeal apparatus;

(C) the effect of mineral fertilization with particular attention to the influence of phosphate fertilization on the bioavailability of As. The P-mobilizing effects on the metalloid have long been proven. The application of $P$ could thus speed up the phytoextration process, as due to chemical similarity with phosphate, plants adsorb arsenate through the phosphor transport system.

Growth of contaminated mature plants and responses to treatment treatments were evaluated by analyzing the main biometric parameters. The biomass of the radical and aerial biomass was examined (Table 6).

Plants have all responded optimally and phosphate fertilization has produced a clear benefit both in terms of both biomass (roots and aerial parts) in relation to the morphological characteristics. The Bromus madritensis presents a lower overall biomass, while Piptatherum miliaceaum showed more uniform data and above all a very extensive and widespread radical apparatus. Probably being Dittrichia viscosa a shrub species has a growth habitus different from Poaceae much 
Citation: Guarino C, Sciarrillo R (2017) Ecological and Functional Evaluation of Species Candidate for Heavy Metals Phytoremediation in SIN Porto Torres (Sardinia, Italy). J Environ Anal Toxicol 7: 484. doi: 10.4172/2161-0525.1000484

Page 7 of 10

\begin{tabular}{|c|c|c|c|c|c|c|c|}
\hline Area & $\mathrm{pH}$ & $\begin{array}{c}\text { Electrical } \\
\text { conductivity at } 25^{\circ} \mathrm{C} \\
(\mu \mathrm{S} \mathrm{cm}-1)\end{array}$ & $\begin{array}{c}\text { CEC } \\
(\mathrm{meq} / 100 \mathrm{~g})\end{array}$ & $\begin{array}{c}\text { Organic Matter } \\
\text { (\% ss) }\end{array}$ & $\begin{array}{l}\text { Total Nitrogen } \\
\text { (\% ss) }\end{array}$ & $\begin{array}{l}\mathrm{P} 205 \\
\mathrm{mg} / \mathrm{kg}\end{array}$ & $\begin{array}{l}\mathrm{K} 2 \mathrm{O} \\
\mathrm{mg} / \mathrm{kg}\end{array}$ \\
\hline 1 & $7.53 \pm 0.34$ & $114.55 \pm 24$ & $14.80 \pm 3$ & $1.97 \pm 0.51$ & $0.17 \pm 0.03$ & $22.46 \pm 7.71$ & $278.62 \pm 112$ \\
\hline 2 & $8.21 \pm 0.07$ & $153.23 \pm 25$ & $16.97 \pm 1.71$ & $2.08 \pm 0.12$ & $0.19 \pm 0.02$ & $58.12 \pm 13$ & $417.19 \pm 170$ \\
\hline 3 & $8.05 \pm 0.07$ & $154.85 \pm 25$ & $10.09 \pm 2$ & $1.44 \pm 0.71$ & $0.13 \pm 0.05$ & $25.71 \pm 10$ & $191.94 \pm 96$ \\
\hline 4 & $7.15 \pm 0.56$ & $94.44 \pm 29$ & $16.49 \pm 3$ & $2.39 \pm 0.69$ & $0.25 \pm 0.06$ & $32.47 \pm 14$ & $246.03 \pm 39$ \\
\hline
\end{tabular}

Table 3: The main chemical characteristics of the Areas 1-4. Values represent mean \pm SE.

\begin{tabular}{|c|c|c|c|c|c|c|}
\hline & \multirow{2}{*}{ Area 1} & \multirow{2}{*}{ Area 2} & \multirow{2}{*}{ Area 3} & \multirow{2}{*}{ Area 4} & \multicolumn{2}{|c|}{ Decree 152/06 } \\
\hline & & & & & $(\mathrm{mg} / \mathrm{kg})^{\mathrm{A}}$ & $(\mathrm{mg} / \mathrm{kg})^{\mathrm{B}}$ \\
\hline As $(\mathrm{mg} / \mathrm{kg})$ & $45.8 \pm 7$ & $46.2 \pm 10$ & $48.2 \pm 3$ & $45 \pm 9$ & 20 & 50 \\
\hline $\mathbf{C d}(\mathrm{mg} / \mathrm{kg})$ & $0.80 \pm 0.16$ & $1.10 \pm 0.34$ & $0.98 \pm 0.28$ & $0.39 \pm 0.17$ & 2 & 15 \\
\hline $\mathrm{Cu}(\mathrm{mg} / \mathrm{kg})$ & $16 \pm 8$ & $16.8 \pm 4$ & $16 \pm 5$ & $4.24 \pm 1.09$ & 120 & 600 \\
\hline $\mathrm{Pb}(\mathrm{mg} / \mathrm{kg})$ & $27.2 \pm 11$ & $28.0 \pm 5$ & $26.6 \pm 10$ & $12.4 \pm 8$ & 100 & 1000 \\
\hline $\mathrm{Zn}(\mathrm{mg} / \mathrm{kg})$ & $63.8 \pm 13$ & $82.0 \pm 11$ & $66.1 \pm 15$ & $63.8 \pm 10$ & 150 & 1500 \\
\hline $\mathbf{V}(\mathrm{mg} / \mathrm{kg})$ & $93.6 \pm 10$ & $113.6 \pm 9$ & $93.2 \pm 10$ & $95.1 \pm 10$ & 90 & 250 \\
\hline T I (mg/kg) & $1.91 \pm 0.05$ & $1.34 \pm 0.03$ & $1.72 \pm 0.02$ & $1.65 \pm 0.02$ & 1 & 10 \\
\hline
\end{tabular}

Table 4: Total concentration of $\mathrm{As}, \mathrm{Cd}, \mathrm{Cu}, \mathrm{Pb}$ and $\mathrm{Zn}(\mathrm{mg} / \mathrm{kg})$ in soils of four areas. Values represent mean $\pm \mathrm{SE}$. ${ }^{\mathrm{A}} \mathrm{Residential}$ soil; ${ }^{\mathrm{B}} \mathrm{Industrial}$ soil.

\begin{tabular}{|c|c|c|c|}
\hline & Area 1 & Area 2 & Area 3 \\
\hline As & $5.00 \pm 0.01$ & $6.08 \pm 0.01$ & $4.07 \pm 0.01$ \\
\hline Cd & $1.06 \pm 0.021$ & $1.12 \pm 0.06$ & $1.09 \pm 0.02$ \\
\hline Cu & $4.45 \pm 0.25$ & $4.64 \pm 0.23$ & $4.65 \pm 0.32$ \\
\hline Pb & $2.55 \pm 0.25$ & $2.23 \pm 0.25$ & $2.64 \pm 0.52$ \\
\hline Zn & $6.64 \pm 0.67$ & $6.53 \pm 0.36$ & $6.68 \pm 0.39$ \\
\hline V & $6.01 \pm 0.05$ & $6.43 \pm 0.06$ & $7.72 \pm 0.05$ \\
\hline TI & $0.21 \pm 0.01$ & $0.23 \pm 0.02$ & $8.04 \pm 1.54$ \\
\hline
\end{tabular}

Table 5: The bioavailable fraction of $\mathrm{As}, \mathrm{Cd}, \mathrm{Cu}, \mathrm{Pb}$ and $\mathrm{Zn}\left(\mathrm{mg} \mathrm{kg}^{-1}\right)$ in soil of four areas. Values represent mean $\pm \mathrm{SE}$.

\begin{tabular}{|c|c|c|c|c|c|c|c|c|c|c|}
\hline \multirow{3}{*}{ Apparatus } & \multirow{3}{*}{ Specie } & \multirow{3}{*}{ Treatment } & \multirow{2}{*}{\multicolumn{2}{|c|}{$\begin{array}{c}\text { Biomass } \\
\text { g s.s. }\end{array}$}} & \multirow{2}{*}{\multicolumn{2}{|c|}{$\begin{array}{c}\text { As } \\
\mathrm{mg} / \mathrm{kg} \mathrm{s.s} .\end{array}$}} & \multirow{2}{*}{\multicolumn{2}{|c|}{$\begin{array}{c}\text { TI } \\
\mathrm{mg} / \mathrm{kg} \mathrm{s} . \mathrm{s} .\end{array}$}} & \multirow{2}{*}{\multicolumn{2}{|c|}{$\frac{\text { V }}{\mathrm{mg} / \mathrm{kg} \mathrm{s.s.}}$}} \\
\hline & & & & & & & & & & \\
\hline & & & Mean & SE & Mean & SE & Mean & SE & Mean & SE \\
\hline \multirow{6}{*}{$\begin{array}{l}\text { Leaves and } \\
\text { stems }\end{array}$} & \multirow{2}{*}{ Dittrichia viscosa } & CONTROL & 2.12 & 0.01 & 12.4 & 0.97 & 1.1 & 0.01 & 18.7 & 1.1 \\
\hline & & $P$ & 2.34 & 0.03 & 16.9 & 1.0 & 1.4 & 0.01 & 21.4 & 1.3 \\
\hline & \multirow{2}{*}{ Piptatherum miliaceaum } & CONTROL & 2.45 & 0.02 & 21.3 & 1.4 & 1.3 & 0.02 & 13.4 & 0.87 \\
\hline & & $P$ & 2.68 & 0.03 & 27.9 & 1.9 & 1.6 & 0.01 & 16.9 & 0.99 \\
\hline & \multirow{2}{*}{ Bromus madritensis } & CONTROL & 1.89 & 0.01 & 7.8 & 0.54 & 0.7 & 0.02 & 3.1 & 0.03 \\
\hline & & $P$ & 2.10 & 0.01 & 10.0 & 0.56 & 1.0 & 0.01 & 4.4 & 0.05 \\
\hline \multirow{6}{*}{ Roots } & \multirow{2}{*}{ Dittrichia viscosa } & CONTROL & 1.10 & 0.04 & 29.8 & 1.5 & 2.8 & 0.04 & 32.1 & 1.8 \\
\hline & & $P$ & 1.29 & 0.01 & 37.4 & 1.9 & 4.6 & 0.01 & 40.0 & 2.0 \\
\hline & \multirow{2}{*}{ Piptatherum miliaceaum } & CONTROL & 1.67 & 0.03 & 31.7 & 1.7 & 3.3 & 0.03 & 26.3 & 1.6 \\
\hline & & $\mathrm{P}$ & 1.98 & 0.02 & 36.4 & 1.8 & 4.9 & 0.02 & 35.6 & 1.9 \\
\hline & \multirow{2}{*}{ Bromus madritensis } & CONTROL & 1.10 & 0.02 & 11.9 & 0.67 & 1.5 & 0.02 & 12.4 & 0.86 \\
\hline & & $\mathrm{P}$ & 1.19 & 0.02 & 14,6 & 0.73 & 2.1 & 0.03 & 13.4 & 0.88 \\
\hline
\end{tabular}

Table 6: Mesocosm: Biomass produced, detected concentration and total away of As, $\mathrm{TI}$ and $\mathrm{V}$. Values represent mean \pm SE. 
Citation: Guarino C, Sciarrillo R (2017) Ecological and Functional Evaluation of Species Candidate for Heavy Metals Phytoremediation in SIN Porto Torres (Sardinia, Italy). J Environ Anal Toxicol 7: 484. doi: 10.4172/2161-0525.1000484

Page 8 of 10

faster in growths. In any case, the biomass found in the mesocosms is in line with the ecological and biological trends of the species being examined. In particular, the beneficial effect of phosphatic fertilization is evidenced (Table 6).

\section{Determination of total content of metal in plants}

Metal concentrations in plants vary with plant species. Plant uptake of heavy metals from soil occurs either passively with the mass flow of water into the roots, or through active transport crosses the plasma membrane of root epidermal cells. Under normal growing conditions, plants can potentially accumulate certain metal ions an order of magnitude greater than the surrounding medium. For As, the bioaccumulation tendencies in the roots are extremely interesting for Piptatherum miliaceaum $(36.4 \pm 1.8 \mathrm{mg} / \mathrm{kg}$ ) and Dittrichia viscosa (37.4 $\pm 1.9 \mathrm{mg} / \mathrm{kg}$ ), also showing good translocation values (Piptatherum miliaceaum: $27.9 \pm 1.9 \mathrm{mg} / \mathrm{kg}$; Dittrichia viscosa : $16.9 \pm 1.0 \mathrm{mg} / \mathrm{kg}$ ) (Table 6). These trends are also confirmed for $\mathrm{Tl}$ and $\mathrm{V}$ (Table 6). In the latter, Dittrichia's performance is very significant.

\section{Plant analysis: Ecophysiology}

The stress markers considered were PAL and GST. The enzyme phenylalanine ammonia lyase (PAL) catalyzes deamination reaction of the amino acid phenyl alanine at the gateway from the primary metabolism into the important secondary phenylpropanoid / phenolic metabolism in plants. Effects of different stresses on PAL activity has been previously reported [27-32]. Regulation of PAL activity in plants is complex, as there are multiple PAL encoding genes, some of which are expressed only in specific tissues or only under certain environmental conditions [33]. The results showed that the activity of PAL significantly increased in leaves of in Dittrichia viscosa and in Piptatherum miliaceaum after the mineral fertilization (Table 7).

Glutathione S-transferases (GSTs) are a superfamily of multifunctional enzymes involved in the antioxidant defenses (phase II metabolism), whose activities have been widely used as a biomarker for predicting the toxicity level of organic pollution. All the specie after the mineral fertilization showed an increase of the enzyme (Table 7). Our results demonstrate a positive correlation between the mineral fertilization and GST activities in Dittrichia viscosa, Piptatherum miliaceaum and Bromus madritensis suggesting that the GST activity is increased by the mineral fertilization.

\section{Conclusion}

The right approach to the possibility of the use of phytoremediation cannot disregard the initial screening of species in the area as they may potentially be the first candidates to build a phytoremediation design. In our case, the species found were small and resonant with the pastoral activity that over the past years has taken place in this area. Substantially, the sheep farming had selected a type of vegetation without allowing the establishment of a pioneer vegetation of the typical evolutionary series of the site. It was a vegetation with low biomass. In fact, in the neighboring areas where there had been no pastoral activity in the past, the vegetation was very different with the presence of sclerophilous species and synantropic vegetation typical of disturbed environments such as Dittrichia viscosa and Piptatherum miliaceum. Therefore, the species in the area are not good candidates to build a phytoremediation design for the low bioavailability, largely due to $\mathrm{pH}$, and the poor predisposition of insistent species on the area to the absorption and detoxification of the heavy me Therefore, it was considered appropriate to experiment with other species which in the literature are documented as tolerants and accumulators of As, $\mathrm{Tl}$ and $\mathrm{V}$ and possibly species having a phytosociological and adaptative context for the area concerned. Therefore, it seemed appropriate to drop our choices on species already naturally present in the area and with robust literature documentation (Dittrichia viscosa and Piptatherum miliaceum) while among the spontaneous species present in the area we have chosen only Bromus madritensis as it has reported interesting results (Supplementary Tables 1 and 2).

The plants used for the mesocosm accumulate the metals in the roots by applying a number of detoxification mechanisms such as chelation in the cytoplasm or storage in the vacuole and in part also have the ability to move the HM by xylotics in the aerial part. These plants respond to external stimuli including heavy metals through different mechanisms. These include (1) sensitivity of external stimuli, (2) transduction and transmission signals in the cell, (3) appropriate activation of HM stress response responses strategies by modulating physiological, biochemical and molecular mechanisms.

In conclusion, Dittrichia viscosa, Piptatherum miliaceum and Bromus madritensis play a key role for the uptake of As, $\mathrm{Tl}$ and $\mathrm{V}$

\begin{tabular}{|c|c|c|c|c|c|c|}
\hline \multirow{3}{*}{ Apparatus } & \multirow{3}{*}{ Specie } & \multirow{3}{*}{ Treatment } & \multicolumn{2}{|l|}{ PAL } & \multicolumn{2}{|l|}{ GST } \\
\hline & & & \multicolumn{2}{|c|}{ ( $\mu \mathrm{g} \mathrm{t}-$ cinnamic acid/h/ $/ \mu \mathrm{g}$ protein) } & \multicolumn{2}{|c|}{ ( $\mu \mathrm{M} / \mathrm{min} / \mu \mathrm{g}$ protein) } \\
\hline & & & Mean & SE & Mean & SE \\
\hline \multirow{6}{*}{ Leaves } & \multirow{2}{*}{ Dittrichia viscosa } & CONTROL & 3.15 & 0.01 & 22.4 & 1.97 \\
\hline & & $P$ & 5.14 & 0.03 & 36.9 & 1.0 \\
\hline & \multirow{2}{*}{ Piptatherum miliaceaum } & CONTROL & 3.04 & 0.02 & 11.5 & 1.4 \\
\hline & & $\mathrm{P}$ & 4.98 & 0.03 & 25.8 & 1.9 \\
\hline & \multirow{2}{*}{ Bromus madritensis } & CONTROL & 2.89 & 0.01 & 12.3 & 1.54 \\
\hline & & $\mathrm{P}$ & 3.90 & 0.01 & 22.0 & 1.56 \\
\hline
\end{tabular}

Table 7: Enzymatic activity of GST ( $\mu \mathrm{M} / \mathrm{min} / \mu \mathrm{g}$ protein) and PAL ( $\mu \mathrm{g}$ t-cinnamic acid/h/ $\mu \mathrm{g}$ protein) in leaves of Dittrichia viscosa, Piptatherum miliaceaum and Bromus madritensis. Values represent mean $\pm \mathrm{SE}$. 
Citation: Guarino C, Sciarrillo R (2017) Ecological and Functional Evaluation of Species Candidate for Heavy Metals Phytoremediation in SIN Porto Torres (Sardinia, Italy). J Environ Anal Toxicol 7: 484. doi: 10.4172/2161-0525.1000484

Page 9 of 10
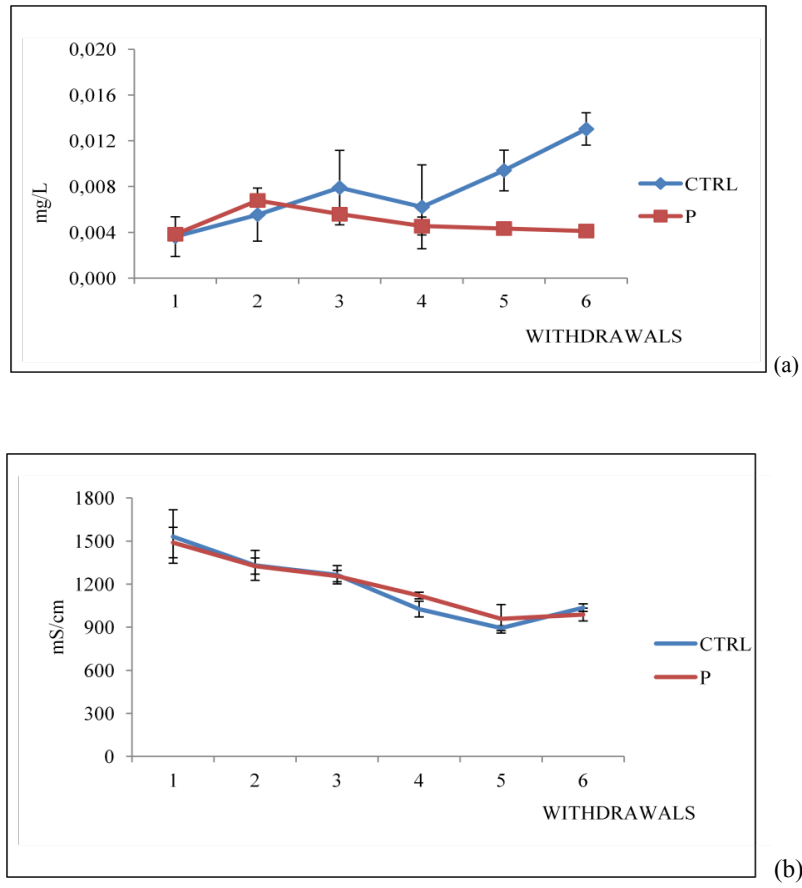

(b)

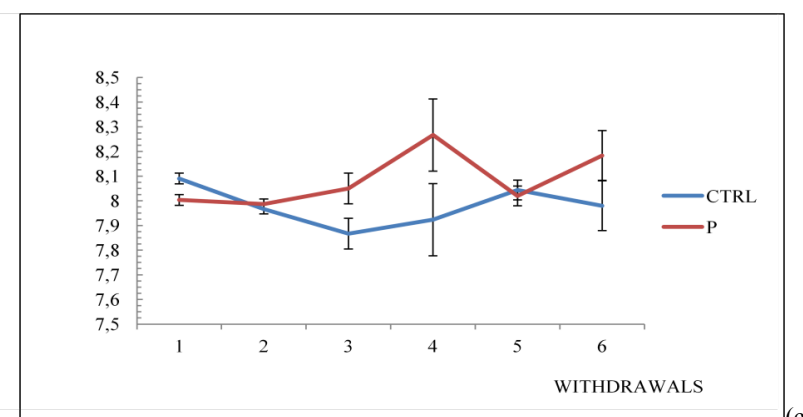

Figure 3: (a) Concentration of As; (b) Electrical Conductivity (EC); (c) pH of the of the leachate harvested from microcosms containing soil from the site of Porto Torres obtained from the subsequent 6 reactions with deionized water (CTRL) and phosphate solution $(P)$.

through a detoxification/seizure process by the storage in vacuole of transporters families such as ABC, CDF, HMA and NRAMP.

\section{References}

1. Marchiol L, Fellet G, Boscutti F, Montella C, Mozzi R, et al. (2013) Gentle remediation at the former "Pertusola Sud" zinc smelter: Evaluation of native species for phytoremediation purposes. Ecol. Eng 53: 343-353.

2. Guarino C, Sciarrillo R (2017) Effectiveness of in situ application of an Integrated Phytoremediation System (IPS) by adding a selected blend of rhizosphere microbes to heavily multi-contaminated soils. Ecol. Eng 99: 70-82.

3. Guarino C, Sciarrillo R (2017) The effectiveness and efficiency of phytoremediation of a multicontaminated industrial site: Porto Marghera (Venice Lagoon, Italy). Chemosphere 183: 371-379.

4. Gallagher FJ, Pechmann I, Bogden JD, Crabosky J, Weis P (2008) Soil metal concentrations and vegetative assemblage structure in an urban brown field. Environ. Pollut 153: 351-361.

5. Luo X, Yu S, Li X (2012) The mobility, bioavailability, and human bioaccessibility of trace metals in urban soils of Hong Kong. Appl. Geochem 27: 995-1004.

6. Yu J, Glazer N, Steinberger Y (2014) Carbon utilization, microbial biomass, and respiration in biological soil crusts in the Negev Desert. Biol Fertil Soils 50: 285-293.

7. Heckenroth A, Rabier J, Dutoit T, Torre F, Prudent P, et al. (2014) Selection of native plants with phytoremediation potential for highly contaminated Mediterranean soil restoration: Tools for a non- destructive and integrative approach. Journal of Environmental Management 12: 1-14.

8. Perez C, Martínez-Sánchez MJ, Martínez-López S, Bolan N (2012) Distribution and bioaccumulation of arsenic and antimony in Dittrichia viscosa growing in mining-affected semiarid soils in southeast Spain. Journal of Geochemical Exploration 123: 128-135.

9. Testiati E, Parinet J, Massiani C, Laffont-Schwob I, Rabier J, et al. (2013) Trace metal and metalloid contamination levels in soils and in two native plant species of a former industrial site: evaluation of the phytostabilization potential. J. Hazard. Mater 248: 131-141.

10. Affholder F, Poeydebat C, Corbeels M, Scopel E, Tittonell P (2013) The yield gap of major food crops in family agriculture in the tropics: assessment and analysis through field surveys and modeling Field Crops Res. 143: 106-118.

11. Miransari M (2011) Interactions between arbuscular mycorrhizal fungi and soil bacteria. Appl Microbiol Biotechnol 89: 917-930.

12. Conesa HM, Schulin R, Nowack B (2007) A laboratory study on revegetation and metal uptake innative plant species from neutral mine tailings. Water, Air, Soil Pollut. 183: 201-212.

13. Murciego AM, Sánchez AG, González MR, Gil EP, Gordillo CT, et al. (2007) Antimony distribution and mobility in topsoils and plants (Cytisus striatus, Cistus ladanifer and Dittrichia viscosa) from polluted Sb-mining areas in Extremadura (Spain). Environmental Pollution 145: 15-21.

14. Jiménez-Martí E, Gomar-Alba M, Palacios A, Ortiz-Julien A, del Olmo ML (2011) Towards an understanding of the adaptation of wine yeasts to must: relevance of the osmotic stress response. Appl Microbiol Biotechnol 89: 1551 1561.

15. Garcia-Salgado S, Garcia-Casillas D, Quijano-Nieto MA, Bonilla-Simon MM (2012) Arsenic and heavy metal uptake and accumulation innative plant species from oils polluted by mining activities. Water, Air, Soil Pollut 223: 559-572.

16. Obeidy C, Bravin MN, Bouchardon JL, Conord C, Moutte J, et al. (2016) Plants increase arsenic in solution but decrease the non-specifically bound fraction in the rhizosphere of an alkaline, naturally rich soil. Ecotoxicol. Environ. Saf 126: $23-29$.

17. Fernández $S$, Poschenrieder $C$, Marcenò $C$, Gallego JR, Jiménez-Gámez D, et al. (2017) Phytoremediation capability of native plant species living on $\mathrm{Pb}-\mathrm{Zn}$ and $\mathrm{Hg}$-As mining wastes in the Cantabrian range, north of Spain. Journal of Geochemical Exploration 174: 10-20.

18. Lindsay WL, Norwell WA (1978) Development of a DTPA soil test for zinc, iron, manganese and copper. Soil Sci. Soc. Am. J 42: 421-428.

19. Pedron F, Petruzzelli G, Barbafieri M, Tassi E (2009) Strategies to use phytoextraction in very acidic soil contaminated by heavy metals. Chemosphere 75: 808-814.

20. Petruzzelli G, Lubrano L, Guidi G (1989) Uptake by corn and chemical extractability of heavy metals from a four year compost treated soil. Plant Soi 116: 23-27.

21. Hudson-Edwards KA, Houghton SL, Osborn A (2004) Extraction and analysis of arsenic in soils and sediments. Trends in Analytical Chemistry 23: 10-11.

22. Al-Najar H, Schulz R, Römheld V (2003) Plant availability of thallium in the rhizosphere of hyperaccumulator plants: a key factor for assessment of phytoextraction. Plant and Soil 241: 97-105.

23. Mahar A, Wang P, Ali A, Awasthi MK, Lahori AH, et al. (2016) Challenges and opportunities in the phytoremediation of heavy metals contaminated soils: A review. Ecotoxicology and Environmental Safety 126: 111-121.

24. Leguizamo MAO, Gomez WDF, Sarmiento MCG (2017) Native herbaceous plant species with potential use in phytoremediation of heavy metals, spotlight on wetlands - A review. Chemosphere 168: 1230-1247.

25. Meletiou-Christou MS, Banilas GP, Diamantoglou S (1998) Seasonal trends in energy contents and storage substances of the Mediterranean species Dittrichia viscosa and Thymelaea tartonraira. Environ. Exp. Bot 39: 21-32. 
Citation: Guarino C, Sciarrillo R (2017) Ecological and Functional Evaluation of Species Candidate for Heavy Metals Phytoremediation in SIN Porto Torres (Sardinia, Italy). J Environ Anal Toxicol 7: 484. doi: 10.4172/2161-0525.1000484

26. Forni C, Frattarelli A, Damiano C (1999) Different size, shape and growth behaviour of cells in suspension cultures of strawberry (Fragaria $x$ ananassa Duch.). Plant Biosyst. 133: 205-212.

27. Janas KM, Cvikrova M, Palagiewicz A, Szafranska K, Posmyk MM (2002) Constitutive elevated accumulation of phenylpropanoids in soybean roots at low temperature. Plant Sci 163: 369-373.

28. Winkel-Shirley B (2002) Biosynthesis of flavonoids and effects of stress. Curr Opin Plant Biol 5: 218-223.

29. Ritter H, Schulz GE (2004) Structural basis for the entrance into the phenylpropanoid metabolism catalyzed by phenylalanine ammonia-lyase. Plant Cell 16: 3426-3436.
30. Gholizadeh A, Kumar M, Balasubramanyam A, Sharma S, Narval S, et al (2004) Antioxidant activity of antiviral proteins from Celosia cristata L. J Plant Biochem. Biotech 13: 13-18.

31. Dixon DP, Skipsey M, Edwards R (2010) Roles for glutathione transferases in plant secondary metabolism. Phytochemistry 718: 338-350.

32. Pawlak-Sprada S, Stobiecki M, Deckert J (2011) Activation of phenylpropanoid pathwayin legume plants expose to heavy metals: part II. Profiling of isoflavonoids and their glycoconjugates induced in roots of lupine (Lupinus luteus) seedlings treated with cadmim and lead. Acta Biochim. Pol. 58: 217223

33. MacDonald MJ, D'Cunha GB (2007) A modern view of phenylalanine ammonia lyase. Biochem Cell Biol 85: 273-282. 